\title{
Pengaruh Boyband Korea sebagai Duta Merek, Kepribadian Merek, dan Gelombang Budaya Korea terhadap Minat Beli Produk Sheet Mask: Studi Kasus pada Merek Mediheal
}

\author{
Naomi Kusumawardani* \\ Program Studi Sarjana Manajemen Bisnis, Sekolah Tinggi Manajemen PPM \\ Jl. Menteng Raya No.9, Kb. Sirih, Kec. Menteng, Kota Jakarta Pusat, Jakarta, Indonesia \\ naoomik96@gmail.com

\section{Anggun Pesona Intan Puspita} \\ Program Studi Sarjana Manajemen Bisnis, Sekolah Tinggi Manajemen PPM \\ Jl. Menteng Raya No.9, Kb. Sirih, Kec. Menteng, Kota Jakarta Pusat, Jakarta, Indonesia \\ anggunppm@gmail.com
}

Diterima: 09-02-2021

Disetujui: 16-06-2021

Dipublikasi: 30-06-2021

\begin{abstract}
ABSTRAK
Penelitian ini bertujuan untuk mengetahui pengaruh boyband Korea sebagai duta merek, kepribadian merek, dan gelombang budaya Korea terhadap minat beli produk sheet mask Mediheal, salah satu produk kecantikan dari Korea. Penelitian ini menggunakan responden wanita berdomisili Jakarta, Bogor, Depok, Tangerang, dan Bekasi sebanyak 121 orang. Teknik pengambilan sampel yang digunakan adalah metode judgement sampling dalam teknik non probability sampling. Data primer yang digunakan dalam penelitian diperoleh dari kuesioner, sedangkan data sekunder diperoleh dari penelitian terdahulu, jurnal, internet dan buku. Penelitian ini menggunakan alat analisis regresi linier berganda dalam menguji pengaruh variabel independen terhadap variabel dependen. Hasil penelitian ini menunjukan bahwa secara simultan boyband Korea sebagai duta merek, kepribadian merek, dan gelombang budaya Korea terhadap minat beli produk sheet mask Mediheal sebesar 51.8\% sedangkan sisanya yakni sebesar $48.2 \%$ dipengaruhi oleh variabel di luar penelitian ini. Secara parsial hanya kepribadian merek dan gelombang budaya Korea yang berpengaruh positif dan signifikan terhadap minat beli produk sheet mask Mediheal.
\end{abstract}

Kata Kunci:

Duta Merek; Kepribadian Merek; Gelombang Budaya Korea; Minat Beli

\begin{abstract}
This study aims to determine the influence of Korean boyband as brand ambassador, brand personality, and Korean wave on purchase intention in sheet mask products from Mediheal brand, one of the beauty products from South of Korea. The sample in this research amounted to 121 women who live in Jakarta, Depok, Tangerang, and Bekasi. The sampling technique used is judgment sampling method in non probability sampling technique. Primary data used in the study were obtained through questionnaires, at the same time the secondary data were collected from previous research, journals, internet, and relevant books. This research used multiple linear regression analysis tools in examining the effect of the independent variables on the dependent variable. The result of this study shows that simultaneously the Korean boyband as brand ambassador, brand personality, and Korean wave on purchase intention to buy Mediheal sheet mask products is $51.8 \%$, while the remaining $48.2 \%$ is influenced by variables outside of this study. Partially, only brand personality and the Korean wave have positive and significant effect on purchase interest in sheet mask products from Mediheal brand.
\end{abstract}

Keywords:

Brand Ambassador; Brand Personality; Korean Wave; Purchase Intention 


\section{PENDAHULUAN}

Menurut Cekindo (2017) sektor produk kosmetik di Indonesia bertumbuh pesat dengan adanya 125.220 produk telah terdaftar di bawah Badan Pengawasan Obat dan Makanan (BPOM) Indonesia selama 5 jangka waktu tahun hingga tahun 2017. Angka tersebut menjadikan produk kosmetik menjadi yang paling unggul dari semua produk yang didaftarkan ke BPOM selama hingga tahun 2017, yakni sebesar 56\%. Badan Pusat Statistik (Putri, 2017) mencatat impor kosmetik Korea Selatan ke Indonesia mencapai 5,9 juta USD pada tahun 2016 dibandingkan dengan tahun 2015 (3,7 juta USD). Dimana artinya, pertumbuhan kosmetik di Indonesia juga merupakan hasil dari impor produk ke dalam negeri.

Salah satu negara yang menjadi pengimpor produk kosmetik ke Indonesia adalah Korea Selatan. Maraknya produk kosmetik asal Korea di kalangan konsumen Indonesia merupakan salah satu dampak dari fenomena gelombang budaya Korea (Korean wave) atau penyebaran budaya pop Korea Selatan secara mendunia. Sheet mask menjadi salah satu jenis produk perawatan wajah yang menjadi tren di kalangan perempuan. Dokter kecantikan, Shilpa Agarwal menyatakan bahwa sheet mask merupakan masker berbentuk lembaran kertas yang terbuat dari kapas dengan campuran serum atau bahan dasar lain yang mengandung sejumlah komponen untuk mengatasi berbagai masalah kulit (Aurelia, 2018).

Mediheal menggunakan BTS (Bangtan Boys) yang merupakan sekelompok boyband asal Korea Selatan sebagai duta merek (brand ambassador). Dengan melihat kesuksesan BTS mencapai kepopuleran dunia. Mediheal memilih boyband asal Korea, yakni Bangtan Boys (BTS) sebagai duta merek karena citra BTS tersebut sesuai dengan citra Mediheal. Mediheal memiliki kepribadian merek (brand personality) yang lebih mengarah ke dimensi sophistication dan excitement, yaitu bersifat high class, mewah, menawan, trendi, dan modern dengan memberikan perawatan estetika yang profesional menggunakan teknologi inovatif dalam produksi. Penggunaan boyband sebagai duta merek dilakukan oleh kosmetik korea sejenis seperti boyband Seventeen duta merek The Saem dan boyband NCT sebagai duta merek Nature Republic.

Mediheal tidak menyediakan toko offline khusus di Indonesia. Penjualan Mediheal secara resmi diatur oleh salah satu situs kosmetik terkemuka, yaitu Sociolla. Penjualan secara offline melalui drugstore. Berdasarkan uraian latar belakang yang telah dituliskan, maka peneliti membuat penelitian dengan judul "Pengaruh Boyband Korea sebagai Duta Merek, Kepribadian Merek, dan Gelombang Budaya Korea terhadap Minat Beli Produk Sheet Mask: Studi Kasus Pada Merek Mediheal".

\section{Rumusan Masalah}

1. Apakah Boyband Korea sebagai duta merek, kepribadian merek, dan gelombang budaya Korea secara simultan berpengaruh signifikan terhadap minat beli produk sheet mask merek Mediheal?

2. Apakah Boyband Korea sebagai duta merek, kepribadian merek, dan gelombang budaya Korea secara parsial berpengaruh positif dan signifikan terhadap minat beli produk sheet mask merek Mediheal? 


\section{Manfaat Penelitian}

1. Manfaat Teoritis: Penelitian ini sebagai bahan kajian dalam ilmu pemasaran sheet mask Mediheal di Indonesia.

2. Manfaat Metodologi: Hasil penelitian diharapkan dapat menjadi bahan acuan selanjutnya mengenai minat beli konsumen.

3. Manfaat Aplikatif: Penelitian ini diharapkan dapat membantu pihak lain seperti manajer pemasaran untuk mengetahui factor-faktor yang mempengaruhi minat beli sheet mask Mediheal

Tinjauan pustaka dengan penelitian sebelumnya yang sejenis atau terkait dilakukan oleh penulis sebelum melakukan penelitian. Penelitian yang dilakukan Ayu Sagia dan Syafrizal Helmi Situmorang pada tahun 2018 dengan judul "Pengaruh Brand Ambassador, Brand Personality Dan Korean Wave Terhadap Keputusan Pembelian Produk Nature Republic Aloe Vera”. Hasil penelitian yang diperoleh dari penelitian tersebut menunjukkan bahwa Brand Ambassador, Brand Personality, dan Korean Wave secara simultan dan parsial berpengaruh positif dan signifikan dalam Keputusan Pembelian skincare Nature Republic Aloe Vera.

\section{Brand}

Menurut The American Marketing Association, brand atau merek merupakan sebuah nama, istilah, tanda, simbol, atau desain atau kombinasi dari beberapa wujud tersebut yang dimaksudkan untuk mengidentifikasikan suatu barang atau jasa dari salah satu penjual untuk membedakan produknya dengan kompetitor (Kotler \& Keller, 2016).

\section{Duta Merek (Brand Ambassador)}

Menurut Turner, Bonner \& Marshall (dalam Gita \& Setyorini, 2016), duta merek (brand ambassador) merupakan ikon budaya atau identitas dimana mereka bertindak sebagai alat pemasaran yang mewakili pencapaian individualisme serta komodifikasi dan komersialisasi suatu produk. VisCAP Model Menurut Royan (dalam Gita \& Setyorini, 2016) menyebutkan bahwa penggunaan duta merek dilakukan pada suatu produk untuk mempengaruhi atau mengajak konsumen sehingga tertarik menggunakan produk, terlebih apabila pemilihan duta merek didasarkan pada pencitraan melalui tokoh terkenal. VisCAP Model menurut Royan (dalam Ningrum, 2016) yaitu Visibility (Popularitas), Credibility (Kredibilitas), Attraction (Daya Tarik), dan Power (Kekuatan).

\section{Kepribadian Merek (Brand Personality)}

Menurut Kotler dan Keller (2016), kepribadian merek merupakan bauran tertentu dari sifat manusia yang dapat kita kaitkan pada suatu merek tertentu. Kotler dan Amstrong (dalam Mulyadi \& Saktiawati, 2003) mengungkapkan manusia sebagai konsumen cenderung memilih merek dengan kepribadian sesuai dengan dirinya. Aaker (1996) mengemukakan skala pengukuran kepribadian merek sesuai dengan Big Five faktor personalitas yakni Sincerity, Excitement, Competence, Sophistication, dan Ruggedness. 


\section{Gelombang Budaya Korea (Korean Wave)}

Gelombang budaya korea meliputi kesadaran global akan berbagai aspek budaya Korea Selatan seperti film atau drama, musik, bahasa Korea, makanan, hingga mode (Kim, 2016). Penelitian Son \& Kijboonchoo (2015) menunjukkan bahwa gelombang budaya Korea dapat menjadi kekuatan bagi Korea Selatan dalam mempromosikan citra negara serta kegiatan ekspor berbagai produk Korea. Citra positif negara Korea yang terbentuk pada masyarakat Indonesia meningkatkan kredibilitas perusahaan dan merek Korea sehingga berdampak pada konsumsi berbagai macam produk Korea (Kim, 2016).

\section{Minat Beli}

Laroche dan Zhol (dalam Riyas \& Herath, 2016) mendefinisikan minat beli (purchase intention) sebagai niat individu untuk membeli produk dari suatu merek yang telah dipilih setelah melakukan evaluasi tertentu. Meskipun Minat beli tidak sama dengan pembelian aktual, namun pengukuran terhadap minat pembelian umumnya digunakan untuk memaksimalkan prediksi terhadap pembelian aktual itu sendiri (Kinnear \& Taylor, 1996). Komponen-komponen indikator dari minat beli yang dijelaskan oleh Schiffman dan Kanuk (1996) sehingga menjadi sebuah dimensi tingkat minat beli konsumen adalah sebagai berikut :

1. Tertarik untuk mencari informasi mengenai produk.

2. Mempertimbangkan untuk membeli produk.

3. Tertarik untuk mencoba produk.

4. Ingin mengetahui produk.

5. Ingin memiliki produk.

\section{Pengembangan Hipotesis}

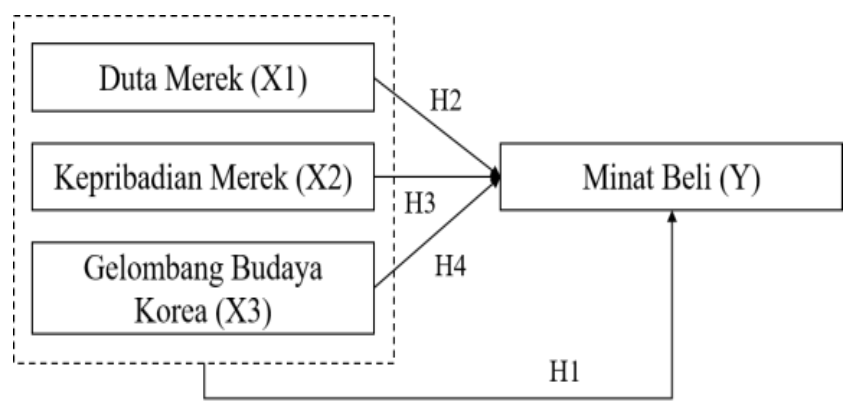

Gambar 1. Kerangka Konseptual Penelitian

\section{METODE RISET}

Penelitian ini menggunakan jenis penelitian deskriptif asosiatif dengan bentuk hubungan kausal/korelasional antara dua variabel atau lebih. Metode penelitian yang digunakan dalam skripsi ini adalah metode penelitian kuantitatif dengan pendekatan survei dan menggunakan kuesioner sebagai alat pengambilan data.

Populasi penelitian merupakan seluruh warga Jabodetabek (Jakarta, Bogor, Depok, Tangerang, dan Bekasi) herjenis kelamin perempuan. Dalam penelitian, pengambilan sampel menggunakan metode 
non probability sampling, dengan jenis teknik judgement sampling. Adapun sampel yang diambil untuk menjawab kuesioner didasarkan pada kriteria sebagai berikut:

1. Perempuan berusia 19 - 35 tahun. Produk Mediheal ditawarkan kepada konsumen dengan harga rata-rata Rp 38.900 sehingga lebih tinggi dibandingkan dengan kompetitor lokal maupun Korea. Pada usia tersebut, responden merupakan mahasiswa atau pekerja yang menjadi target pasarnya

2. Berdomisili di Jabodetabek.

Dalam menentukan ukuran sampel dari suatu populasi digunakan rumus perhitungan jumlah sampel yang dikemukakan oleh Rao Purba (1996, dalam Sulistyari (2012) sebagai berikut :

$\mathrm{n}=\frac{Z^{2}}{4(M \circ e)^{2}}$

Dengan menggunakan margin of error sebesar 10\%, maka jumlah sampel minimal yang dapat diambil sebesar : $\mathrm{n}=1,96^{2} / 4(0,10)^{2} \mathrm{n}=96,04$ atau dapat dibulatkan menjadi 97 Berdasarkan perhitungan di atas, maka sampel yang digunakan dalam penelitian berjumlah minimal 97 responden.

Pengumpulan data primer menggunakan kuesioner dikirimkan kepada responden dalam format Google survei dan disebarkan melalui media online. Skala likert 4 skala digunakan untuk mengukur sikap, pendapat, serta persepsi seseorang atau sekelompok mengenai suatu fenomena sosial (Ridwan \& Kuncoro dalam Stefani, 2013). Peneliti akan melakukan pengolahan data menggunakan SPSS yakni, uji kualitas instrumen, uji asumsi klasik, uji analisis regresi linear berganda, uji hipotesis, dan koefisien determinasi.

\section{HASIL PENELITIAN DAN PEMBAHASAN}

\section{Hasil Kualitas Instrumen}

Uji coba kuesioner dilakukan kepada 30 responden dengan memberikan 25 butir pernyataan yang dibagi menjadi 4 variabel, yakni duta merek, kepribadian merek, gelombang budaya Korea, dan minat beli untuk menguji validitas dan reliabilitas seluruh pernyataan pada kuesioner.

\section{Hasil Uji Validitas}

Dalam uji validitas, peneliti menggunakan Corrected Item-Total Correlation dan Pearson ( $\mathrm{r}$ hitung) yang dibandingkan dengan r-tabel. Semua item indikator dinyatakan valid sebab nilai corrected item-total correlation dan Pearson ( $\mathrm{r}$-hitung) $>\mathrm{r}_{\text {tabel }}$ sebesar 0,394 dengan signifikan 0,05 sehingga valid digunakan sebagai alat pengumpulan data dalam penelitian.

\section{Hasil Uji Reliabilitas}

Dalam uji reliabilitas, peneliti menggunakan nilai Cronbach's Alpha untuk mengukur keandalan seluruh item pernyataan dalam kuesioner. Hasil menunjukan bahwa nilai Cronbach's Alpha pada total item masing-masing variabel memiliki nilai $>0.80$, sehingga dapat disimpulkan bahwa seluruh item pernyataan sangat reliabel untuk digunakan sebagai alat pengumpulan data. 


\section{Gambaran Umum Responden}

Responden penelitian merupakan perempuan berdomisili Jakarta, Bogor, Depok, Tangerang, atau Bekasi berusia antara 19-35 tahun. Produk Mediheal ditawarkan kepada konsumen dengan harga rata-rata Rp 38.900,- per produk sehingga diasumsikan pada usia tersebut, responden merupakan mahasiswa atau pekerja dengan uang saku atau penghasilan lebih tinggi dibandingkan usia di bawah kriteria tersebut. Mayoritas responden sebesar 82\% merupakan perempuan usia antara 19-22 tahun. Profesi mayoritas responden sebesar 73\% adalah mahasiswa. Dari 121 responden, mayoritas yakni sebanyak 37 orang mengeluarkan biaya Rp 150.001 hingga Rp 300.000 per bulan untuk perawatan wajah.

\section{Analisis Deskriptif}

Hasil output kuesioner, mayoritas responden sudah mengetahui sheet mask Mediheal melalui media sosial seperti Instagram, Twitter, Facebook yakni dipilih sebesar 35,18\%. Sedangkan, drugstore lokasi penjualan offline resmi produk Mediheal dipilih sebesar 20,1\% oleh responden.

\section{Analisis Distribusi Jawaban}

Tabel 1. Mean per Variabel

\begin{tabular}{lc}
\hline \multicolumn{1}{c}{ Variabel } & Mean \\
\hline Duta Merek $\left[\mathrm{X}_{1}\right]$ & 3,24 \\
Kepribadian Merek $\left[\mathrm{X}_{2}\right]$ & 3,17 \\
Gelombang Budaya Korea $\left[\mathrm{X}_{3}\right]$ & 2,87 \\
Minat Beli [Y] & 3,05 \\
\hline \multicolumn{2}{c}{ Sumber: Pengolahan Data (2019) }
\end{tabular}

\section{Hasil Uji Asumsi Klasik}

\section{Hasil Uji Normalitas}

Peneliti menggunakan 2 macam uji yakni grafik normal probability plot dan rasio Skewness \& Kurtosis. Berdasarkan hasil grafik plot, dapat terlihat bahwa data menyebar di sekitar garis diagonal serta mengikuti arah garis dan tidak melebar. Data yang diperoleh memenuhi persyaratan untuk analisis regresi linear berganda.

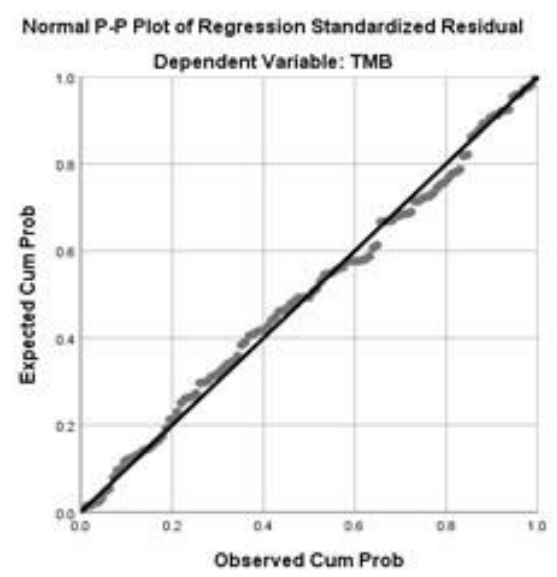

Gambar 2. Hasil Uji Normalitas Plot Sumber: Pengolahan Data (2019) 
Tabel 2. Hasil Uji Skewness

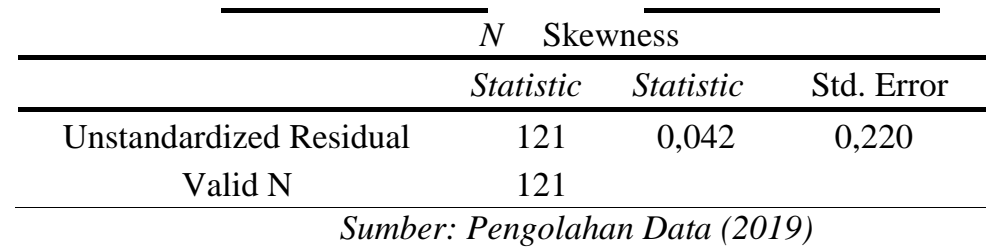

Perhitungan z-Skewness dapat dilakukan dengan membagi nilai statistic dengan std. error, yakni $0,042 / 0,220=0,191$.

Tabel 3. Hasil Uji Kurtosis

\begin{tabular}{cclc}
\hline & $N$ & \multicolumn{2}{c}{ Kurtosis } \\
\hline & Statistic & Std. Statistic Error \\
\hline Unstandardized Residual & 121 & 0.380 & 0.437 \\
Valid N & 121 & & \\
\hline \multicolumn{3}{c}{ Sumber: Pengolahan Data (2019) }
\end{tabular}

Perhitungan z-Kurtosis dapat dilakukan dengan membagi nilai statistic dengan std. error, yakni $0,380 / 0,437=0,87$. Nilai z-Skewness dan z-Kurtosis tersebut $<1,96$, maka dapat dikatakan bahwa data berdistribusi normal.

\section{Hasil Uji Heteroskedastisitas}

Pada grafik scatterplot menunjukan bahwa titik-titik menyebar secara acak serta tidak membentuk pola baik di atas maupun di bawah angka 0 pada sumbu Y. Menurut hasil grafik tersebut pada model regresi, tidak terjadi heteroskedastisitas sehingga model regresi layak digunakan untuk memprediksi minat beli produk sheet mask Mediheal berdasarkan variabel independen yang ditentukan

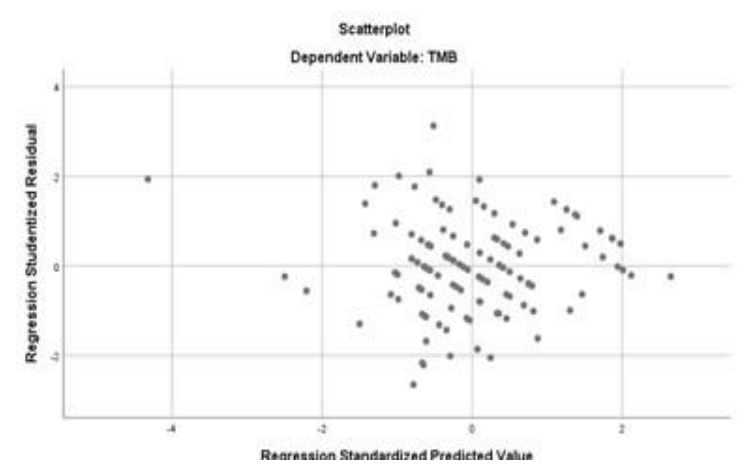

Gambar 3. Hasil Scatterplot Heteroskedastisitas Sumber: Pengolahan Data (2019)

\section{Hasil Uji Multikolinearitas}

Tabel 4. Hasil Nilai Tolerance dan VIF

\begin{tabular}{ccc}
\hline & \multicolumn{2}{c}{ Collinearity Statistics Variabe 1} \\
\cline { 2 - 3 } & Tolerance & VIF \\
\hline TBA $\left[\mathrm{X}_{1}\right]$ & 0,616 & 1,623 \\
TBP $\left[\mathrm{X}_{2}\right]$ & 0,684 & 1,462 \\
TKW $\left[\mathrm{X}_{3}\right]$ & 0,819 & 1,221 \\
\hline \multicolumn{2}{c}{ Dependent Variable : TMB } \\
\hline \multicolumn{2}{c}{ Sumber: Pengolahan Data (2019) }
\end{tabular}


Berdasarkan tabel hasil nilai Tolerance pada bagian collinearity statistics pada variabel duta merek $\left(X_{1}\right)$, kepribadian merek $\left(X_{2}\right)$, dan gelombang budaya Korea $\left(X_{3}\right)>0,10$. Nilai VIF pada variabel duta merek $\left(X_{1}\right)$, kepribadian merek $\left(X_{2}\right)$, dan gelombang budaya Korea $\left(X_{3}\right)<10$. Sehingga menunjukkan model garis regresi tidak terjadi multikolinearitas.

\section{Persamaan Regresi Linear Berganda}

Penelitian ini dirancang untuk meneliti lebih dari satu variabel bebas terhadap satu variabel terikat. $\mathrm{Y}=a+\mathrm{b} 1 \mathrm{X} 1+\mathrm{b} 2 \mathrm{X} 2+\mathrm{b} 3 \mathrm{X} 3+\ldots+\mathrm{bn} \mathrm{Xn}$. Dengan keterangan sebagai berikut: $\mathrm{Y}=$ Variabel terikat yang diproyeksikan. $a=$ Nilai konstanta harga $\mathrm{Y}$ jika $\mathrm{X}=0, \mathrm{~b}=$ Nilai arah penentu prediksi yang menunjukkan nilai peningkatan $(+)$ atau nilai penurunan (-) variabel terikat. $\mathrm{X}_{\mathrm{n}}=$ Variabel bebas yang memiliki nilai tertentu untuk diprediksikan.

Tabel 5. Analisis Regresi Berganda

\begin{tabular}{cccc}
\hline Variabel & Koefisien Regresi & t-hitung & Sig. \\
\hline Konstanta & 1,835 & & \\
TBA $\left[\mathrm{X}_{1}\right]$ & $-0,137$ & $-2,207$ & 0,029 \\
\hline \multicolumn{5}{c}{} \\
\hline TBP $\left[\mathrm{X}_{2}\right]$ & 0,661 & 10,004 & 0,000 \\
TKW $\left[\mathrm{X}_{3}\right]$ & 0,074 & 2,049 & 0,043 \\
F hitung & 44,007 & & \\
RSquare & 0,530 & & \\
\hline \multicolumn{4}{c}{ Sumber: Pengolahan Data (2019) }
\end{tabular}

Berdasarkan tabel di atas dapat diperoleh rumus persamaan regresi linear berganda sebagai berikut:

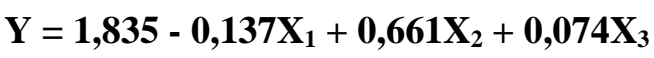

Dari hasil persamaan regresi linear berganda sederhana yang diperoleh dapat dijabarkan arti sebagai berikut:

1. Konstanta (a) sebesar 1,835 menyatakan, jika variabel $\mathrm{X}$ tidak ada nilai atau 0 maka nilai minat beli (Y) sebesar 1,835.

2. Koefisien regresi variabel bebas pertama $\left(b_{1}\right)$ sebesar $-0,317$ menyatakan bahwa setiap penambahan 1 nilai untuk variabel $\mathrm{X}_{1}$, maka nilai $\mathrm{Y}$ berkurang sebesar 0,317.

3. Koefisien regresi variabel bebas kedua $\left(b_{2}\right)$ sebesar 0,661 menyatakan bahwa setiap penambahan 1 nilai $\mathrm{X}_{2}$, maka nilai $\mathrm{Y}$ bertambah sebesar 0,661.

4. Koefisien regresi variabel bebas ketiga $\left(b_{3}\right)$ sebesar 0,074 menyatakan bahwa setiap penambahan 1 nilai untuk variabel $\mathrm{X}_{3}$, maka nilai $\mathrm{Y}$ bertambah sebesar 0,074 .

\section{Uji Hipotesis Simultan (Uji F)}

Berdasarkan hasil tabel Anova uji regresi menggunakan SPSS, nilai $F_{\text {hitung }}$ yang diperoleh sebesar 44,007. Sedangkan $F_{\text {tabel }}$ dengan jumlah 'n' 121 dan ' $k$ ' berjumlah 3 didapatkan nilai sebesar 2,70. Demikian, $F_{\text {hitung }} 44,007>F_{\text {tabel }} 2,70$ atau signifikansi $0,000<0,05$. Sehingga disimpulkan bahwa hipotesis $\mathrm{H}_{1}$ diterima $\mathrm{H}_{\mathrm{o} 1}$ ditolak artinya duta merek, kepribadian merek, gelombang budaya Korea secara simultan berpengaruh signifikan terhadap minat beli produk sheet mask. 
Kusumawardhani, N. \& Puspita, A.P.I. (2021). Pengaruh Boyband Korea Sebagai Duta Merek ....

Tabel 6. Hasil Uji F (ANOVA)

\begin{tabular}{lccccc}
\hline \multicolumn{1}{c}{ Model } & Sum of Squares & df & Mean Square & F & Sig. \\
\hline Regression & 451,699 & 3 & 150,566 & 44,007 &, $000^{\mathrm{b}}$ \\
Residual & 400,301 & 117 & 3,421 & & \\
Total & 852,000 & 120 & & & \\
a. & Dependent Variable :TMB & & \\
b. & Predictors : (Constant), TKW, TBP, TBA & & \\
\hline \multicolumn{5}{c}{ Sumber: Pengolahan Data (2019) }
\end{tabular}

\section{Hasil Hipotesis Parsial (Uji t)}

\begin{tabular}{lccc}
\multicolumn{4}{c}{ Tabel 7. Hasil Uji t } \\
\hline \multicolumn{1}{c}{ Variabel } & t-hitung & t-tabel & Sig. \\
\hline Duta Merek $\left[\mathrm{X}_{1}\right]$ & $-2,207$ & 1,981 & 0,029 \\
Kepribadian Merek $\left[\mathrm{X}_{2}\right]$ & 10,004 & 1,981 & 0,000 \\
Gelombang Budaya Korea $\left[\mathrm{X}_{3}\right]$ & 2,049 & 1,981 & 0,043 \\
\hline \multicolumn{4}{c}{ Dependent Variable : TMB (Minat Beli) } \\
\hline \multicolumn{4}{c}{ Sumber: Pengolahan Data (2019) }
\end{tabular}

Hasil nilai $t_{\text {hitung }}$ pada output SPSS yang diperoleh untuk menguji pengaruh variabel bebas terhadap variabel terikat secara parsial dapat dijabarkan arti sebagai berikut:

1. Variabel duta merek secara parsial berpengaruh negatif dan signifikan terhadap minat beli, bukti terlihat dari nilai $\mathrm{t}_{\text {hitung }}(-2,207)<\mathrm{t}_{\text {tabel }}(1,981)$ dengan tingkat signifikan sebesar 0,029 $<0,05$. Sehingga $\mathrm{H}_{2}$ ditolak $\mathrm{H}_{02}$ diterima, yakni Boyband Korea sebagai duta merek secara parsial tidak berpengaruh positif dan signifikan terhadap minat beli produk sheet mask Mediheal.

2. Variabel kepribadian merek secara parsial berpengaruh positif dan signifikan terhadap minat beli, hal ini terlihat dari nilai $t_{\text {hitung }}(10,004)>t_{\text {tabel }}(1,981)$ dengan tingkat signifikan sebesar 0,000 $<0,05$. Sehingga $\mathrm{H}_{3}$ diterima $\mathrm{H}_{03}$ ditolak, yakni kepribadian merek Mediheal secara parsial berpengaruh positif dan signifikan terhadap minat beli produk sheet mask Mediheal.

3. Variabel gelombang budaya Korea secara parsial berpengaruh positif dan signifikan terhadap minat beli sheet mask Mediheal, terlihat dari nilai $t_{\text {hitung }}(2,049)>t_{\text {tabel }}(1,981)$ dengan tingkat signifikan sebesar $0,043<0,05$. Sehingga $\mathrm{H}_{4}$ diterima $\mathrm{H}_{04}$ ditolak.

\section{Hasil Uji Koefisien Determinasi $\left(\mathbf{R}^{2}\right)$}

Tabel 8. Hasil Koefisien Determinasi

\begin{tabular}{cccc}
\hline Model & $\mathrm{R}$ & $\begin{array}{c}\text { Adjusted R } \\
\text { Square }\end{array}$ & $\begin{array}{c}\text { Std. Error of the } \\
\text { Estimate }\end{array}$ \\
\hline 1 & 0,72 & 0,518 & 1,850 \\
8 & & \\
\hline \multicolumn{3}{c}{ Predictors: (Constant), TKW, TBP, TBA } \\
Dependent Variable: TMB (Minat Beli) \\
\hline \multicolumn{3}{r}{ Sumber: Pengolahan Data (2019) }
\end{tabular}

Berdasarkan hasil SPSS pada tabel Model Summary, diperoleh hasil koefisien $\left(\mathrm{R}^{2}\right)$ sehingga diketahui:

1. Nilai R sebesar 0,728 sebagai arti hubungan variabel duta merek $\left(X_{1}\right)$, kepribadian merek $\left(X_{2}\right)$, dan gelombang budaya Korea $\left(\mathrm{X}_{3}\right)$ terhadap minat beli (Y) produk sheet mask Mediheal sebesar $72,8 \%$. 
2. Nilai Adjusted $R$ Square sebesar 0,518 memberikan arti bahwa 51,8\% variasi minat beli (Y) dapat dijelaskan oleh variabel duta merek $\left(\mathrm{X}_{1}\right)$, kepribadian merek $\left(\mathrm{X}_{2}\right)$, dan gelombang budaya Korea $\left(\mathrm{X}_{3}\right)$, sedangkan $48,2 \%$ dijelaskan oleh variabel di luar persamaan regresi ini atau variabel yang tidak diteliti.

3. Nilai Std. error of the estimate sebesar 1,850, semakin kecil nilai tersebut berarti model semakin baik.

\section{Diskusi Penelitian}

Setelah melakukan analisis pengolahan data, hasil penelitian dalam perhitungan hipotesis secara parsial diperoleh hasil bahwa duta merek $\left(\mathrm{X}_{1}\right)$ Boyband Korea berpengaruh negatif $(2,207)$ dengan signifikan $(0,029)$, artinya $\mathrm{H}_{2}$ ditolak $\mathrm{H}_{02}$ diterima. Dalam studi penelitian terdahulu oleh Hendra (2014) yang berjudul "Pengaruh Selebriti Iklan IM3 Versi JKT 48 terhadap Minat Beli Menurut Model Viscap (Survey pada SMA Negeri 7 Yogyakarta)" mendapatkan bahwa hasil uji t menunjukan variabel Visibility $\left(\mathrm{X}_{1}\right)$ dan Credibility $\left(\mathrm{X}_{2}\right)$ tidak ada pengaruh positif, hanya Attraction $\left(\mathrm{X}_{3}\right)$ dan Power $\left(\mathrm{X}_{4}\right)$ sebagai pengaruh positif iklan IM3 JKT48 terhadap minat beli.

Mendukung hasil penelitian, dilakukan pengajuan pertanyaan terbuka untuk mendalami jawaban responden yang diberikan kepada 5 responden. Pertanyaan pertama yang diajukan, "Menurut Anda, kriteria atau aspek seperti apa yang harus dimiliki seorang/sekelompok duta merek produk sheet mask Mediheal?". Secara garis besar mayoritas responden mengungkapkan duta merek membutuhkan aspek daya tarik fisik seperti kulit mulus, cerah, dan bersih. Duta merek perlu menampilkan manfaat dari produk itu sendiri. 2 dari 5 responden mengatakan bahwa jenis kelamin wanita lebih sesuai sebagai duta merek produk Mediheal dan wanita tersebut harus berpenampilan menarik. Sedangkan 1 dari 5 responden menyebutkan bahwa ketentuan jenis kelamin tertentu tidak terlalu penting karena skin care merupakan produk unisex.

Pertanyaan terbuka kedua adalah “Apa opini Anda mengenai Bangtan Boys (BTS) sebagai duta merek untuk menarik minat beli sheet mask Mediheal?". Menurut 2 dari 5 orang responden mengungkapkan bahwa penggunaan Bangtan Boys sebagai duta merek sesuatu yang tidak wajar, namun Mediheal ingin membuat sudut pandang bahwa baik laki-laki maupun perempuan perlu untuk merawat wajah. Menurut 2 dari 5 responden menyebutkan kembali perihal jenis kelamin perempuan lebih baik sehingga sebagai sesama perempuan tentu dapat lebih terhubung. Menurut 1 dari 5 responden mengatakan bahwa bagi penggemar Kpop, Bangtan Boys akan menarik minat beli. Namun, bagi sekelompok orang yang tidak menyukai Kpop, penggunaan Bangtan Boys kurang menarik. Menurut 1 dari 5 responden menyebutkan penggunaan duta merek tidak terlalu penting untuk menarik minat beli dirinya terhadap suatu produk. Menurut 1 dari 5 responden menyebutkan penggunaan Bangtan Boys sebagai duta merek menarik minat jangka pendek dikarenakan kemasan dan bonus hadiah yang unik. 


\section{KESIMPULAN DAN SARAN}

\section{Kesimpulan}

Berdasarkan pendeskripsian dan penafsiran hasil penelitian dan pengujian hipotesis diperoleh hasil sebagai berikut :

1. Variabel duta merek, kepribadian merek, dan gelombang budaya Korea secara simultan berpengaruh signifikan terhadap minat beli sebesar $51,8 \%$, sedangkan sisanya yaitu $48,2 \%$ dijelaskan oleh variabel lain yang tidak diteliti.

2. Variabel duta merek $\left(\mathrm{X}_{1}\right)$ secara parsial tidak ada pengaruh positif terhadap minat beli.

3. Variabel kepribadian merek $\left(\mathrm{X}_{2}\right)$ secara parsial berpengaruh positif dan signifikan terhadap minat beli sebesar $76,6 \%$ terhadap minat beli.

4. Variabel gelombang budaya Korea $\left(\mathrm{X}_{3}\right)$ secara parsial berpengaruh positif dan signifikan terhadap minat beli sebesar 14,3\% terhadap minat beli.

Menurut hasil dari pemaparan ketiga variabel, dapat diketahui bahwa variabel kepribadian merek berpengaruh paling besar dan dominan terhadap minat beli produk sheet mask Mediheal. Bauran sifat dari merek atau produk membuat hubungan yang kuat dengan sifat konsumen sehingga menarik minat beli.

\section{Saran Peneliti Akademik Selanjutnya}

Dalam melakukan penelitian, peneliti menghadapi keterbatasan penelitian antara lain, dalam penyebaran kuesioner online terdapat kemungkinan bahwa responden tidak serius dalam memberikan jawaban, keterbatasan ruang lingkup sampel, dan keterbatasan variabel yang diteliti. Berdasarkan hasil penelitian yang tentu masih jauh dari kata sempurna, penelitian masih memiliki kemungkinan besar untuk ditindaklanjuti dan dikembangkan kembali. Hal yang dapat dikembangkan dalam penelitian selanjutnya yaitu:

1. Penelitian selanjutnya dapat memberlakukan uji beda pengaruh duta merek terhadap minat beli untuk kelompok penyuka Bangtan Boys, kelompok yang biasa saja dengan Bangtan Boys, dan kelompok yang tidak suka Bangtan Boys. Sehingga hasil pengaruh akan menemukan temuan lebih spesifik mengenai target konsumen yang perlu dicapai.

2. Penelitian selanjutnya dapat memperbanyak serta memperluas sampel responden.

3. Penelitian selanjutnya dapat membahas mengenai faktor atau dimensi lain di luar variabel yang telah diteliti pada penelitian ini.

\section{Saran Implikasi Peningkatan Minat Beli}

Penggunaan Bangtan Boys sosok Boyband sebagai duta merek produk kosmetik masih menjadi suatu hal yang baru bagi konsumen Indonesia. Tidak hanya Mediheal, namun juga untuk merek Korea lain yang menggunakan duta merek laki-laki. Bangtan Boys memiliki banyak penggemar perempuan sehingga diharapkan dapat meningkatkan minat beli, namun peningkatan minat beli ini terjadi hanya pada produk khusus bertemakan Bangtan Boys yang berakhir dengan konsumsi jangka pendek. Dalam 
sebuah penelitian berjudul "Fenomena Endorsement di Instagram Story pada Kalangan Selebgram." dilakukan wawancara berkaitan endorsement salah satu selebriti Instagram (selebgram), Rachel Venya. Dampak peningkatan jumlah pengikut akun Instagram toko dan jumlah pembeli dirasakan oleh penjual setelah menggunakan jasa Rachel Venya (Ramadhan dkk., 2020). Salah satu pengikut Instagram Rachel Venya mengaku bahwa alasan tertarik membeli produk pakaian karena adanya pengaruh review dari Rachel (Ramadhan dkk., 2020). Apabila konsumen Indonesia belum dapat menerima budaya baru, Mediheal Indonesia dapat menggunakan beauty Influencer untuk mempengaruhi minat beli konsumen. Sosok beauty influencer ini dapat melakukan aktivitas interaktif melalui media sosial. Hasil penelitian mendukung penggunaan media sosial karena mayoritas responden memilih media sosial (70 kali) sebagai alat pencarian informasi produk Mediheal. 


\section{DAFTAR PUSTAKA}

Aaker, D. A. (1996). Building Strong Brands. New York: The Free Press.

Aurelia, J. (2018, Maret 1). Sheet Mask Selfie, Gaya Selfie Masa Kini. Retrieved from Tirto.id: https://tirto.id/sheet-mask-selfie-gaya-selfie-masa-kini-cFrt

Cekindo Group. (2018). Registrasi Produk Kosmetik. Retrieved from Cekindo: https://www.cekindo.com/id/blog/registrasi-produk-kosmetik

Gita, D. dan Setyorini, R. (2016). Pengaruh Brand Ambassador Terhadap Brand Image Perusahaan Online Zalora.co.id. e-Proceeding of Management, 620-626.

Hendra, W. O. (2014). Pengaruh Selebriti Iklan IM3 Versi JKT48 Terhadap Minat Beli Menurut Model Viscap (Survey Pada SMA Negeri 7 Yogyakarta). Yogyakarta: Fakultas Ilmu Sosial dan Humaniora Universitas Islam Negeri Sunan Kalijaga.

Kim, H. (2016, Februari 2). Surfing The Korean Wave: How K-pop is Taking Over The World. Retrieved from http://www.mcgilltribune.com/a-e/surfing-the-korean-wave-how-k-pop-kpop-is-takingover-theworld-012858/

Kinnear, T. C. dan Taylor, J. R. (1996). Marketing Research: An Applied Approach. New York: Mc Graw-Hill.

Kotler, P. dan Keller, K. L. (2016). Marketing Management. Edinburgh: Pearson Education Limited.

Mediheal US. (2018). About Us. Retrieved from Mediheal US: https://medihealus.com/pages/about-us

Mulyadi, H. dan Saktiawati, D. (2008). Pengaruh Brand Personality Terhadap Loyalitas Pelanggan Shampo Sunsilk. Jurnal Strategic, 20-76.

Ningrum, N. S. (2016). Pengaruh Brand Ambassador Terhadap Minat Beli Konsumen MD Clinic By Lazeta. Bisnis dan Iptek, 141-152.

Purba, R. (1996). Measuring Consumer Perceptions Through Factor Analysis. The Asian Manager (February - March), 23-28.

Putri, R. D. (2017, Oktober 23). Indonesia, Target Pasar Seksi K-Beauty di Asia. Retrieved from 
Ramadhan, A., Naswandi, C. N., dan Herman, C. M. (2020). The Phenomenon of Instagram Story Endorsement Among Selebgrams. Kareba Jurnal Ilmu Komunikasi, 317-329

Riyas, M. dan Herath, H. (2016). Impact of Brand Personality Determinants towards Purchasing Intention: A Study on Branded Umbrella Products in Sri Lanka. Kelaniya Journal of Management, 4757.

Sagia, A. dan Situmorang, S. H. (2018). Pengaruh Brand Ambassador, Brand Personality Dan Korean Wave. Jurnal Manajemen Bisnis Indonesia, 286-298.

Schiffman, L. G. dan Kanuk, L. L. (1997). Consumer Behavior. New Jersey: Prentice Hall.

Son, S. dan Kijboonchoo, T. (2016). The Impact of Korean Wave on the Purchase Intention of Korean Cosmetics of Thai People in Bangkok and Chonburi, Thailand. PSAKUIJIR, 76-83.

Stefani, S. (2013). Analisis Pengaruh Iklan Televisi, Celebrity Endorser, Kualitas Produk, dan Citra Merek Terhadap Keputusan Pembelian Pada Produk Kosmetik Berlabel Halal "Wardah". Jakarta: Universitas Islam Negeri Syarif Hidayatullah.

Sulistyari, I. N. (2012). Analisis Pengaruh CItra Merek, Kualitas Produk, dan Harga terhadap Minat Beli Produk Oriflame (Studi Kasus Mahasiswi Fakultas Ekonomika dan Bisnis Jurusan Manajemen Universitas Diponegoro Semarang). Semarang: Universitas Diponegoro.

Tirto.id: https://tirto.id/indonesia-target-pasar-seksi-k-beauty-di-asia-cyRj/ 


\section{LAMPIRAN}

Tabel Uji Validitas Duta Merek $\left(\mathbf{X}_{1}\right)$

\begin{tabular}{ccrc}
\hline BA & $\begin{array}{c}\text { Corrected Item-Total } \\
\text { Correlation }\end{array}$ & r-hitung & r-tabel \\
\hline BA1 & 0,727 & 0,796 & 0,349 \\
BA2 & 0,700 & 0,774 & 0,394 \\
BA3 & 0,664 & 0,782 & 0,394 \\
BA4 & 0,872 & 0,916 & 0,394 \\
BA5 & 0,867 & 0,894 & 0,394 \\
BA6 & 0,685 & 0,803 & 0,394 \\
\hline \multicolumn{4}{c}{ Sumber: Pengolahan Data (2019) }
\end{tabular}

Tabel Uji Validitas Kepribadian Merek $\left(\mathbf{X}_{2}\right)$

\begin{tabular}{cccc}
\hline BP & $\begin{array}{c}\text { Corrected Item-Total } \\
\text { Correlation }\end{array}$ & r-hitung & r-tabel \\
\hline BP1 & 0,739 & 0,801 & 0,349 \\
BP2 & 0,644 & 0,748 & 0,394 \\
BP3 & 0,655 & 0,760 & 0,394 \\
BP4 & 0,741 & 0,817 & 0,394 \\
BP5 & 0,527 & 0,658 & 0,394 \\
BP6 & 0,614 & 0,736 & 0,394 \\
BP7 & 0,702 & 0,799 & 0,394 \\
\hline \multicolumn{4}{c}{ Sumber: Pengolahan Data (2019) }
\end{tabular}

Tabel Uji Validitas Gelombang Budaya Korea $\left(\mathbf{X}_{3}\right)$

\begin{tabular}{cccc}
\hline KW & $\begin{array}{c}\text { Corrected Item- } \\
\text { Total Correlation }\end{array}$ & r-hitung & r-tabel \\
\hline KW1 & 0,838 & 0,883 & 0,349 \\
KW2 & 0,744 & 0,807 & 0,394 \\
KW3 & 0,763 & 0,829 & 0,394 \\
KW4 & 0,817 & 0,871 & 0,394 \\
KW5 & 0,864 & 0,903 & 0,394 \\
KW6 & 0,815 & 0,867 & 0,394 \\
KW7 & 0,874 & 0,911 & 0,394 \\
\hline \multicolumn{4}{c}{ Sumber: Pengolahan Data (2019) }
\end{tabular}

Tabel 9. Uji Validitas Minat Beli (Y)

\begin{tabular}{cccc}
\hline MB & $\begin{array}{c}\text { Corrected Item-Total } \\
\text { Correlation }\end{array}$ & r-hitung & r-tabel \\
\hline MB1 & 0,757 & 0,837 & 0,349 \\
MB2 & 0,829 & 0,889 & 0,394 \\
MB3 & 0,803 & 0,897 & 0,394 \\
MB4 & 0,771 & 0,854 & 0,394 \\
MB5 & 0,766 & 0,867 & 0,394 \\
\hline \multicolumn{3}{c}{ Sumber: Pengolahan Data (2019) }
\end{tabular}

Tabel Hasil Uji Reliabilitas Variabel

\begin{tabular}{cccc}
\hline Variabel & Cronbach 's Alpha & Jumlah Item & Status \\
\hline X1 & 0,901 & 6 & Sangat reliabel \\
X2 & 0,873 & 7 & Reliabel \\
X3 & 0,945 & 7 & Sangat reliabel \\
Y & 0,916 & 5 & Reliabel \\
\hline \multicolumn{4}{c}{ Sumber: Pengolahan Data (2019) }
\end{tabular}

